\title{
Septal Defect Repair
}

National Cancer Institute

\section{Source}

National Cancer Institute. Septal Defect Repair. NCI Thesaurus. Code C148075.

Any surgical repair of a septal defect. 